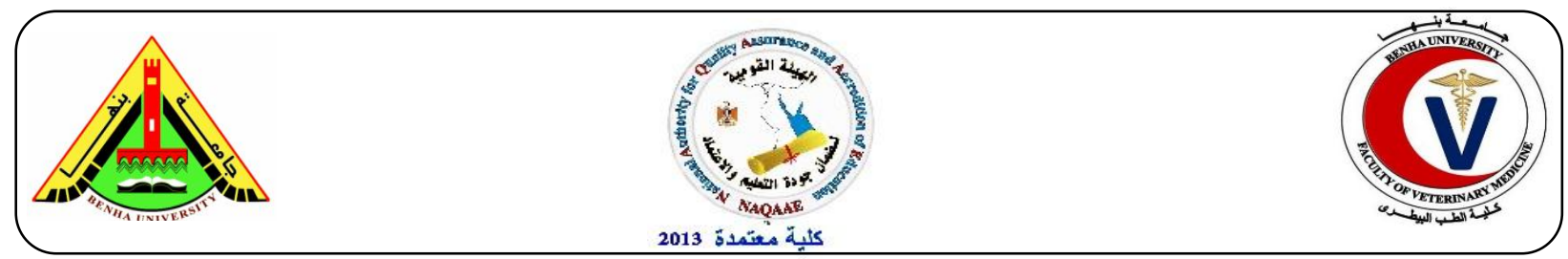

\title{
Bacteriological and Molecular Identification of some Campylobacter Species in Broilers and their Macrolide Resistance Profile
}

Ashraf A. Abd El Tawab ${ }^{1}$, Ahmed A. Ammar ${ }^{2}$, Heba A. Ahmed ${ }^{3}$, Fatma I. El Hofy ${ }^{1}$, Ahmed A. Hefny $^{4 *}$

${ }^{I}$ Department of Bacteriology, Immunology and Mycology, Faculty of Veterinary Medicine, Benha University, PO 13736 Moshtoher, Benha, Egypt; ${ }^{2}$ Microbiology Dep., Fac. Vet. Med. Zagazig University, ${ }^{3}$ Zoonoses Dep., Fac. Vet. Med. Zagazig University, ${ }^{4}$ Veterinary Hospital, Fac. Vet. Med. Zagazig University.

*Corresponding author: Email: (ahmed_vet8_2007@yahoo.com), Tel.: +(20)1223600435

\section{A B S T R A C T}

Genus campylobacter including several species is of great importance that is considered among the major causative agents of acute diarrheal diseases in humans worldwide. The current study was carried out to determine the occurrence of thermotolerant campylobacters in broilers and to identify the macrolides resistance profiles of $C$. jejuni and $C$. coli isolates. A total of 568 samples (364 cloacal swabs and 51 of each breast meat, thigh meat, caecal part and neck skin) were collected from broiler chickens at slaughter age from local pluck shop outlets in Zagazig city, Sharkia Governorate, Egypt. The isolation rate of Campylobacter species from neck skin, breast meat, cloacal swabs, thigh meat and caecal parts samples was $25.5 \%, 27.5 \%, 29.3 \%, 31.4 \%$ and $41.2 \%$, respectively. C. jejuni was isolated from cloacal swabs, skin, thigh meat, breast meat and caecal parts samples with the isolation rate of $55.3 \%, 53.8 \%, 43.7 \%, 50 \%$ and $80.9 \%$, respectively. Forty-two campylobacter isolates (28 and 14 biochemically suspected $C$. jejuni and $C$. coli isolates, respectively) were confirmed molecularly depending on $23 \mathrm{~S}$ rRNA gene. Furthermore, real time PCR targeting hip $\mathrm{O}$ gene specific for $C$. jejuni and glyA specific for $C$. coli were used. The molecularly confirmed isolates were evaluated they macrolides resistance pattern which revealed that all isolates were resistant to macrolides. Further studies on the mechanisms of macrolides resistance in campylobacters are essential.

Keywords: $C$. jejuni, $C$. coli, broiler, rtPCR, macrolide, Egypt

(BVMJ, 34 (1), 2018)

\section{INTRODUCTION}

Campylobacter is considered an emerging foodborne disease (EFSA and ECDC, 2015), which was recognized as a major cause of human illnesses ranging from gastroenteritis to sever illness;
Guillain-Barre Syndrome (Moore et al., 2005).

Poultry is a natural host of Campylobacter spp. and the broiler chicken gut especially the caeca is often colonized by C. jejuni in particular (EFSA, 2008). Campylobacter spp. are Gram-negative, 
curved rods within the family campylobacteriacae (Zilbauer et al., 2008), which require specific growth conditions for an optimal growth (Bronnec et al., 2016).

Amongst campylobacters, thermophilic Campylobacter species are implicated in food borne infections (Iovine et al., 2008). C. jejuni and C. coli are recognized as the major cause of acute gastroenteritis in human throughout the world. C. jejuni is most frequently reported as a cause of human campylobacteriosis (8090\%) compared to C. coli (5-10\%) (EFSA, 2008).

Hippurate hydrolysis is the only phenotypic test differentiating $C$. jejuni from other species of campylobacters, especially the thermophilic species. The two biotypes of $C$. jejuni (C. jejuni subspp. jejuni and subspp. doylei) are capable of hydrolyzing sodium hippurate to benzoic acid and glycine (ISO, 2006). However, recently, hippurate negative $C$. jejuni strains have been reported in several studies (Waino et al., 2003). For instance, Takkinen et al. (2002), documented $2.5 \%$ false positive hippurate hydrolysis results and 39\% false negative results.

Gastroenteritis caused by campylobacter infection is usually selflimiting and require no antimicrobial treatment except in severe and immunocompromised patients (Belanger and Shryock, 2007). Fluoroquinolones (FQ) and macrolides are the most commonly used antibiotics in the treatment of campylobacter infections (Da Silva et al., 2016). However, the rapid significant increase in the prevalence of $\mathrm{FQ}$ and macrolides resistant strains isolated from broiler sources
(Neimann et al., 2003), is recognized as the major health problem worldwide (Griggs et al., 2005). The increased resistance has been reported due to the un-controlled use of antibiotics especially in poultry industry (Chang et al., 2015).

The aim of the current work was to investigate the prevalence of Campylobacter species particularly $C$. jejuni in broiler chicken samples by using conventional and molecular tools. Also, identifying the macrolides resistance profile of $C$. jejuni and C. coli isolates using both minimum inhibitory concentration and disc diffusion methods.

\section{MATERIAL AND METHODS}

\subsection{Samples:}

A total of 568 samples were collected from broiler chickens at slaughter age (6 weeks) from local pluck shop outlets in Zagazig city, Sharkia Governorate, Egypt. The samples comprised of 364 cloacal swabs and 51 of each breast meat, thigh meat, caecal part and neck skin. The study was carried out during the period from September 2015 to July 2017. The collected samples were aseptically transported as soon as possible in an ice box to the laboratory for bacteriological examination.

\subsection{Samples preparation:}

\subsubsection{Poultry cloacal swabs:}

Sterile swabs were inserted into the cloaca, and then directly immersed into tubes containing sterile preston enrichment broth medium (Ellerbroek et al., 2010).

\subsubsection{Poultry skin, meat and caecal samples:}

Twenty five grams of each breast meat, thigh meat, incised skin and caecal 
samples were aseptically transferred to a sterile blender containing $225 \mathrm{ml}$ of preston enrichment broth for homogenization then enriched (Sallam, 2001).

\subsection{Bacteriological examination:}

2.3.1. Isolation of Campylobacter species:

For isolation of Campylobacter species, the collected samples in preston enrichment broth were incubated at $42^{\circ} \mathrm{C}$ for 24-48 hours with less than $1 \mathrm{~cm}$ of headspace left in the culture vessel with tightly capped lids (Oxoid, 2006). After enrichment, $0.1 \mathrm{ml}$ of the broth was streaked onto modified campylobacter selective agar; mCCDA containing CCDA selective supplement. The plates were then incubated at $42^{\circ} \mathrm{C}$ in darkness for 48 hours under microaerophilic conditions $\left(5 \% \mathrm{O}_{2}, \quad 10 \%\right.$ $\mathrm{CO}_{2}$ and $85 \% \mathrm{~N}_{2}$ ) using CampyGen sachets (Vandepitte and Verhaegen, 2003).

\subsubsection{Preliminary confirmation of thermophilic Campylobacter species}

Thermophilic Campylobacter species were preliminary identified by their colonial morphology on mCCDA media. Suspected colonies were purified on 5-7\% lysed horse blood agar plates and subjected to Gram staining, testing of motility, growth at $25^{\circ} \mathrm{C}$ and $41.5^{\circ} \mathrm{C}$ and oxidase test (ISO, 2006).

\subsubsection{Biochemical identification of Campylobacters:}

The preliminary identified Campylobacter species were further subjected to catalase test, oxidase test, susceptibility to nalidixic acid and cephalothin and rapid hippurate hydrolysis test (Nachamkin, 1999).

2.4. Molecular identification of isolates:

2.4.1. DNA extraction:

DNA extraction from the biochemically identified isolates was performed according to the manufacturer guidelines using Bacterial DNA Extraction Kit (Spin-column) (BioTeke Corporation, China).

\subsubsection{Confirmation of Campylobacter spp. by PCR:}

A conventional PCR targeting $650 \mathrm{bp}$ of 23S rRNA specific for Campylobacter spp. was used for the confirmation of 42 biochemically identified campylobacter isolates (Wang et al., 2002). The sequences of primers are Camp-F 5'TATACCGGTAAGGAGTGCTGGAG-3' and Camp-R 5'- ATCAATTAACC TTCGAGCACCG-3'.

2.4.3. Confirmation of $C$. jejuni and $C$. coli isolates by real time PCR (rtPCR):

A real time probe based PCR (rtPCR) reaction was used for the confirmation of 28 biochemically identified $\mathrm{C}$. jejuni isolates using species-specific primer and TaqMan probe sets targeting hipO gene specific for C. jejuni (LaGier et al., 2004). The sequences of primers and probe are $\mathrm{Cj}-\mathrm{F} 5^{2}$ 'TGCTAGTGAGGTTGCAAAAGAATT-3', Cj-R 5'-TCATTTCGCAAAAAAA TCCAAA-3' and Cj-FAM 5'ACGATGATTAAATTCACAATTTTTTTC GCC AAA-3'. Also, 14 suspected C. coli isolates were confirmed by the amplification of glyA gene (LaGier et al., 2004). The sequences of primers and probe are $\mathrm{Cc}-\mathrm{F} 5$ 'CATATTGTAAAACCAAAGCTTATCGG3', Cc-R 5'- AGTCCAGCAAT GTGTGCAATG-3' and Cc-VIC 5'TAAGCTCCAACTTCATCCGCAATCTCT C TAAATTT-3'. Non-template DNA and positive controls of C. jejuni, C. coli, E. coli, S. Typhimurium, Staph. aureus and two 
biochemically identified Campylobacter isolates other than C. jejuni and C. coli were also run to determine the specificity of the reaction.

\subsection{Antimicrobial susceptibility testing} (determination of phenotypic resistance): 2.5.1 Disk diffusion method (Qualitative susceptibility testing):

A total of 28 C. jejuni and 14 C. coli isolates were examined for their susceptibility to macrolides by the disk diffusion method on Müeller-Hinton agar supplemented with 5\% of lysed horse blood $50 \%$ following the NCCLS recommendations (CLSI, 2012). Campylobacter jejuni NCTC 11322 / ATCC $^{\circledR} 29428$ was used as a quality control. The used macrolides antibiotics (Oxoid) were erythromycin $\left(\mathrm{E}_{15} \mu \mathrm{g}\right)$, clarithromycin $\left(\mathrm{CLR}_{15} \mu \mathrm{g}\right)$, azithromycin $\left(\mathrm{AZM}_{15} \mu \mathrm{g}\right)$ and Spiramycin $\left(\mathrm{S}_{100} \mu \mathrm{g}\right)$. Tylosin $\left(\mathrm{TLS}_{5}\right)$ was not commercially available in the form of discs and prepared from powder (Sigma Aldrich) using Whatman filter paper no. 1.

\subsubsection{Broth microdilution method} (quantitative susceptibility testing):

Two-fold broth microdilution method was used to determine the minimum inhibitory concentrations (MIC) of $28 C$. jejuni and 14 C. coli strains against macrolides agents using Müeller Hinton broth according to Clinical and Laboratory Standards Institute guidelines (CLSI, 2012).

\subsubsection{Interpretation of antimicrobial susceptibility tests}

The interpretation criteria for the susceptibility testing of Campylobacter spp. for erythromycin, clarithromycin, tylosin and azithromycin were according to EUCAST (2017). The interpretation criteria for tylosin were used the breakpoints given for erythromycin. The criteria for spiramycin and tylosin were following the recommendations of Ca-SFM (2013).

\section{RESULTS}

\subsection{Preliminary confirmation of thermophilic Campylobacter species}

Campylobacter species were preliminary identified by their colonial morphology on mCCDA and sheep blood agar. The colonies appeared greyish, flat, moistened, with a tendency to spread and they may have a metal sheen suggesting $C$. jejuni isolates. Creamy-grey moist and more discrete colonies suggested that the colonies belong to C. coli. Additionally, on 5-7\% lysed horse blood agar Campylobacter spp. had characteristic colonies of oil drop like appearance (translucent droplet-like colonies), slightly pink, round, convex, smooth and shiny, with regular edges. Occasionally, Campylobacter spp. showed greyish, flat, moistened, with a tendency to spread on lysed horse blood agar.

Campylobacter species were also confirmed by production of oxidase, the results were indicated by intense deep purple color appearance within few seconds on oxidase strip. The suspected Campylobacter organisms in freshly prepared cultures appeared as Gram negative (faint in color) curved bacilli. In old cultures, or when exposed to air for prolonged time periods, colonies transformed from spiral form to coccoid morphology.

Examination of motility under oil immersion lens showed that campylobacters are highly motile with characteristic corkscrew like motility, while in old cultures they were less motile. Moreover, 
thermophilic campylobacters did not grow at $25^{\circ} \mathrm{C}$ in a microaerobic atmosphere or at $41.5^{\circ} \mathrm{C}$ aerobically for 48 hours.

\subsection{Identification of Campylobacter species:}

The results showed that all examined isolates $(n=167)$ were positive for catalase production. All campylobacter isolates $(100 \%)$ were resistant to nalidixic acid, therefore, it was difficult to differentiate $C$. lari and $C$. coli, while, $C$. jejuni was differentiated by rapid Sodium hippurate hydrolysis test. The results of Sodium hippurate hydrolysis test revealed that 95 out of $167(56.9 \%)$ of isolates were positive, classifying them as $C$. jejuni.

\subsection{Occurrence of Campylobacter spp. in different samples:}

According to the phenotypic identification; Campylobacter spp. were isolated from $29.4 \%$ of the examined samples. The results demonstrated a high isolation rate of Campylobacter spp. in chickens from caecal part (41.2\%), followed by thigh meat (31.4\%), cloacal swabs (29.3\%) and breast meat (27.5\%).

Identification of campylobacters to the species level showed that $C$. jejuni, $C$. coli/C. lari and $C$. hyointestinalis were identified in 56.9, 40.1 and $3 \%$ of the examined samples, respectively. The highest isolation rate of $C$. jejuni was detected in caecal parts $(80.9 \%)$, followed by cloacal swabs (55.3\%), neck skin (53.8\%) and breast meat $(50 \%)$. The lowest isolation rate was in thigh meat (43.7\%), (Table 1). 3.4. Molecular confirmation of
representative campylobacter isolates:

3.4.1. Confirmation of campylobacter isolates by conventional PCR:

Forty-two campylobacter isolates (28 and 14 biochemically suspected $C$. jejuni and C. coli isolates, respectively) were confirmed by the amplification of 23S rRNA gene; an amplicon of $650 \mathrm{bp}$ size was generated using conventional PCR.

\subsubsection{Confirmation of $C$. jejuni and C. coli isolates by rtPCR:}

Real time PCR targeting hipO gene specific for $C$. jejuni and glyA specific for $C$. coli were used for the confirmation of the selected phenotypically identified isolates. The results showed that all $28 C$. jejuni and 14 C. coli isolates were confirmed by rtPCR. The specificity of the reactions was confirmed when primers and probes targeting hip $\mathrm{O}$ and glyA genes did not amplify DNA from other controls.

\subsection{Antimicrobial susceptibility testing:}

The results obtained from both methods revealed that all $C$. jejuni and $C$. coli isolates were resistant to antimicrobials of macrolides class. To overcome the difficulty in reading MIC results due to the presence of LHB, resazurin was used and recording of the results was based on the observation of color change. Active viable bacterial cells reduce the reagent (purple blue) to pink colorless. The MIC after adding resazurin indicator was defined as the lowest antibiotic concentration that prevented the reagent color change (Figures: 1). The results of broth microdilution method revealed that $C$. jejuni and $C$. coli isolates were $100 \%$ resistant to antibiotics of FQ and macrolides classes. 
Table 1: Occurrence of different Campylobacter spp. in the examined samples

\begin{tabular}{|c|c|c|c|c|c|}
\hline \multirow[b]{2}{*}{$\begin{array}{l}\text { Type of } \\
\text { samples }\end{array}$} & \multirow[b]{2}{*}{$\begin{array}{l}\text { Number } \\
\text { examined }\end{array}$} & \multicolumn{4}{|c|}{ Number (proportion \%) } \\
\hline & & $\begin{array}{c}\text { Total } \\
\text { campylobacter } \\
\text { isolates* }\end{array}$ & C. jejuni** & $\begin{array}{l}\text { C. coli / } \\
\text { C. lari** }\end{array}$ & $\begin{array}{c}C . \\
\text { hyointestinalis** }^{* *}\end{array}$ \\
\hline Cloacal swabs & 364 & $103(28.3 \%)$ & $57(55.3 \%)$ & $42(40.8 \%)$ & $4(3.9 \%)$ \\
\hline Neck skin & 51 & $13(25.5 \%)$ & $7(53.8 \%)$ & $6(46.2 \%)$ & $0(0 \%)$ \\
\hline Breast meat & 51 & $14(27.5 \%)$ & $7(50 \%)$ & $7(50 \%)$ & $0(0 \%)$ \\
\hline Thigh meat & 51 & $16(31.4 \%)$ & $7(43.7 \%)$ & $9(56.3 \%)$ & $0(0 \%)$ \\
\hline Caecal parts & 51 & $21(41.2 \%)$ & $17(80.9 \%)$ & $3(14.3 \%)$ & $1(4.8 \%)$ \\
\hline Total & 568 & $167(29.4 \%)$ & $95(56.9 \%)$ & $67(40.1 \%)$ & $5(3 \%)$ \\
\hline
\end{tabular}

* The isolation rate was calculated in relation to the total number of the examined samples.

** The isolation rate of each species was calculated in relation to the total no. of the isolated campylobacters.

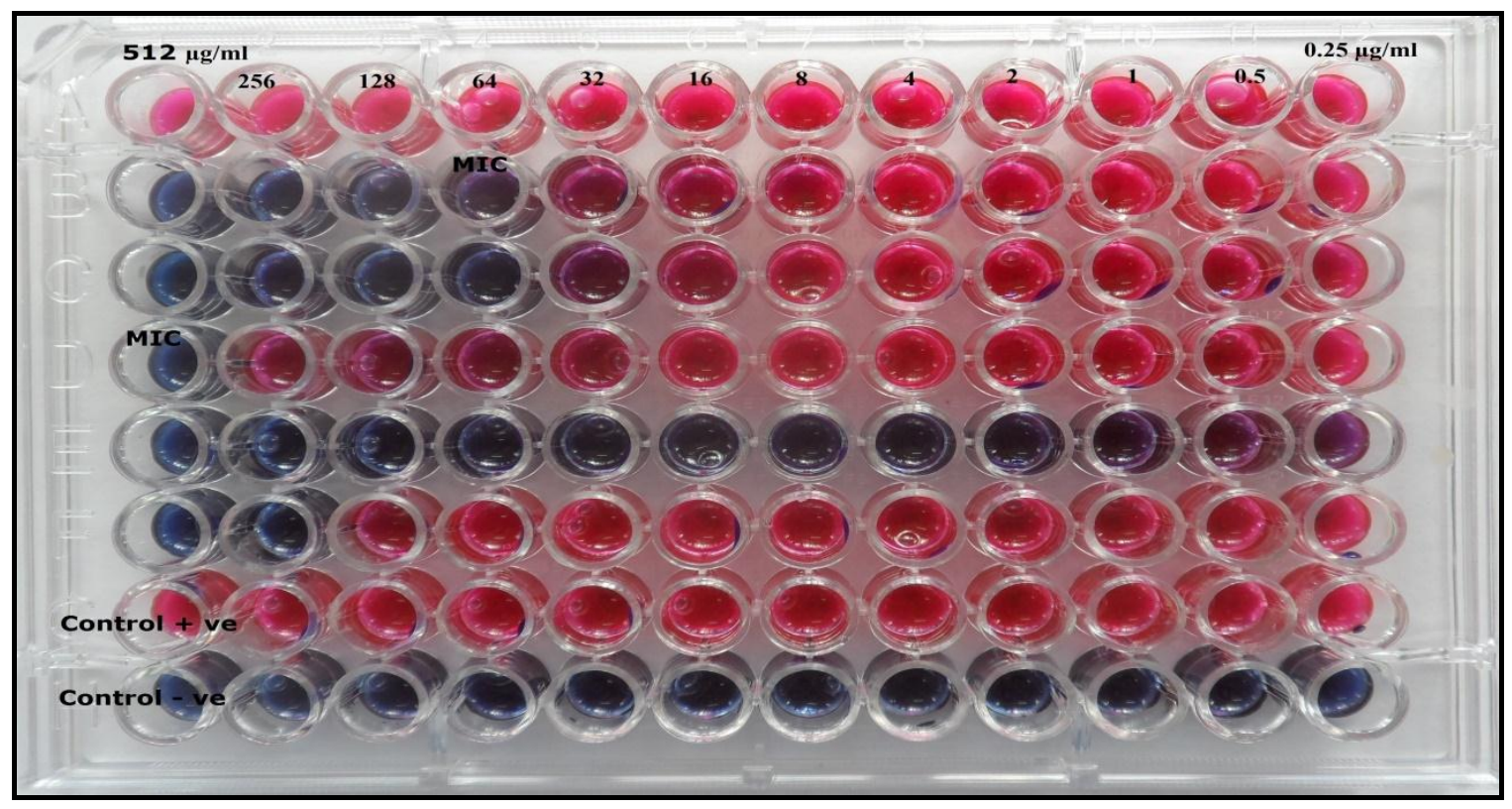

Figure 1: Reading results of broth microdilution test using resazurin reagent. Positive results; pink color, Negative results; blue or purple color, MIC; the lowest antibiotic concentration that prevented the reagent color change (blue color).

\section{DISCUSSION}

For the identification of thermophilic campylobacters to the species level, catalase test, susceptibility to nalidixic acid and cephalothin and rapid hippurate hydrolysis test were performed. In the current study, the results showed that all campylobacter isolates were resistant to nalidixic acid. As a result, differentiation between $C$. jejuni, $C$. lari and $C$. coli based on the susceptibility to nalidixic acid was difficult. 
The judgment on hippurate hydrolysis test which differentiates $C$. jejuni from $C$. coli isolates, is usually based on qualitative criteria which are not reliable and may lead to misinterpretation (Megraud, 1987). Thus, isolates which were used for further investigations for the detection of $\mathrm{FQ}$ and macrolides resistance were confirmed by PCR.

In the current study, Campylobacter spp. were isolated from $29.3 \%$ cloacal swabs. Similar isolation rate of $29 \%$ from broiler flocks was reported in Japan (Sabike et al., 2017). Nearly similar results of $35.1 \%$ (Abd El-Tawab et al., 2015) and 21.6\% (Awadallah et al., 2014) were reported in Egypt. Comparable isolation rates of $31.9 \%$ in Vietnam (Carrique-Mas et al., 2014) and $39.2 \%$ in Estonia (Mäesaar et al., 2014), were also reported.

Different studies reported higher prevalence rates of Campylobacter spp., for instance; 58\% in Brazil (Da Silva et al., 2016), 85\% in Algeria (Messad et al., 2014) and $57 \%$ in NewZeland (Anderson et al., 2012). The aforementioned higher isolation rates could be attributed to the isolation of Campylobacter spp. from fresh fecal samples on the ground. The farm ground near poultry houses are suspected to be highly contaminated with Campylobacter spp. from different sources such as wild birds, rodents and free living pets (Studer et al., 1999). In addition, Pezzotti et al. (2003) and Salihu et al. (2012) reported higher isolation rates of $82.9 \%$ in Italy and $51.5 \%$ in Nigeria from chicken cloacal swabs, respectively. Such higher percentages compared to the obtained results during the current study could be a result of campylobacter identification by only conventional methods in the two studies reported in Nigeria and Italy. However, an isolation rate of $69.8 \%$ from chicken cloacal swabs determined by PCR in Tanzania was reported (Mdegela et al., 2006). The authors attributed such high percentage to the extensive type of chicken management that increases the exposure of birds to campylobacter infection through insects, rodents, contaminated water and poor housing hygiene (Mdegela et al., 2006).

Lower Campylobacter spp. isolation rates of $1.5 \%$ and $6.9 \%$ from cloacal swabs were reported in Greece (Marinou et al., 2012) and Italy (Menna et al., 2005). The authors attributed the low isolation rate to strict biosecurity measures observed in the examined farms.

Out of the 103 campylobacter isolates from cloacal swabs, $55.3 \%$ were identified as $C$. jejuni. Comparable percentages of $46 \%$ in Egypt (Abd El-Tawab et al., 2015) and $68.1 \%$ in Argentina (Zbrun et al., 2015), were reported.

Higher isolation rates of $C$. jejuni were reported in different studies; $90 \%$ in Great Britain (Jorgensen et al., 2011) and 89\% in Vietnam (Carrique-Mas et al., 2014). However, lower prevalence rate of $31.4 \%$ was obtained in Reunion Island (Henry et al., 2011). In Greece, C. coli was only identified from chicken cloacal swabs (Marinou et al., 2012). The authors attributed such results to the type of feed ration because $C$. jejuni do not frequently colonize in birds receiving plant protein based feed (Udayamputhoor et al., 2003). 
Poultry is exposed to campylobacters at farm level due to insufficient biosecurity measures at the market outlets due to contamination of carcasses during different slaughtering processes (Parkar et al., 2013). Campylobacter spp. were isolated from 27.5 and $31.4 \%$ of the examined breast and thigh meat samples, respectively. Comparable percentages of campylobacters were reported in chicken meat; $34.1 \%$ in Japan (Stella et al., 2017), 21.7\% in Ethiopia (Dadi and Asrat, 2016) and 29.1\% in Greece (Economou et al., 2015).

Higher isolation rates of campylobacters were documented; $61.6 \%$ in Italy (Pedonese et al., 2017), 63.1\% in China (Zhu et al., 2016) and 58.8\% in Korea (Wei et al., 2016). While lower isolation rates of $17 \%$ in Brazil (Da Silva et al., 2016) and $17.2 \%$ in China (Zhang et al., 2016), were also reported.

The variation in Campylobacter spp. isolation rates among the previously mentioned studies could be attributed to difference in the sanitation levels during handling and processing of chicken, season of sampling and the laboratory methodologies employed for isolation (Shih, 2000).

C. jejuni was isolated from 43.7 and $50 \%$ of thigh and breast meat samples, respectively. Comparable percentage of $C$. jejuni isolation from chicken meat were documented in several studies; for instance, $41.9 \%$ in Italy (Pedonese et al., 2017) and $52.5 \%$ in Korea (Wei et al., 2016). Higher isolation rates of $76.9 \%$ in China (Zhang et al., 2016) and $88.8 \%$ in Estonia (Mäesaar et al., 2015), were reported.
The obtained results in the current study were lower than those reported in Japan where $C$. jejuni isolates were identified from 86.2 and $78.6 \%$ of breast meat and thigh meat samples, respectively (Sallam, 2007). However, in Egypt, Saad (2014) reported the identification of $C$. jejuni from $6.9 \%$ of the examined thigh meat samples.

Chicken skin provides suitable microenvironment for the survival of campylobacters due to accumulation of water which increases the surface area available for bacterial contamination (Miwa et al., 2003). The isolation rate of campylobacters from skin samples was $25.5 \%$, of which, $53.8 \%$ were identified as C. jejuni.

Different studies also reported the isolation of Campylobacter spp. from chicken skin samples; 68\% in Sweden (Hansson et al., 2015), 30.8\% in Egypt (Abd El-Tawab et al., 2015) and 68\% in Sweden (Hansson et al., 2015).

The detection of campylobacter in carcass skin varied significantly due to the fact that the slaughtering process varies between different slaughter houses and the degree of external contamination of the feathers during transport to slaughter can vary (Hansson et al., 2015).

Manual slaughtering and evisceration, which is common in poultry pluck-shops based markets in Egypt, where fecal content leakage is common, may result in contaminating chicken meat (breast and thigh meat) and skin. The same observation was reported by Huang et al. (2016) in China and Saad (2014) in Egypt. The authors 
concluded that chicken from wet markets that devoid hygienic measures were frequently and heavily contaminated with campylobacter.

Campylobacter spp. are ubiquitous foodborne pathogens that colonize the intestinal tract of chicken especially the caeca (Silva et al., 2011). Campylobacter spp. isolation rate of $41.2 \%$ from chicken caecal parts was obtained in the current study, of which, $80.9 \%$ were identified as $C$. jejuni. Comparable results were also reported as $56.1 \%$ in China (Han et al., 2016) and 41\% in Egypt (Abd El-Tawab et al., 2015).

Higher isolation rates were previously obtained; $100 \%$ in Sweden (Hansson et al., 2015) and 98\% in Algiers (Messad et al., 2014).

Gblossi Bernadette et al. (2012) reported that Campylobacter spp. are better detected by direct examination of the intestine than in the case of cloacal swabs. Such assumption was based on the fact that cecum is the main colonization site of Campylobacter spp. in chicken (Silva et al., 2011). The aforementioned higher isolation rates could be attributed to the isolation of campylobacters from caecal contents, where the load of bacteria could reach $10^{10}$ organisms per gram of caecal content (Silva et al., 2011).

The variation in Campylobacter spp. isolation rate between different studies could be attributed to different possible reasons, such as the type and site of the examined samples (Meremäe et al., 2010). Moreover, the seasonal factors, biosecurity, husbandry and management and production system have the greatest impact on the prevalence rate of campylobacters (Chatur et al., 2014; Newell et al., 2011).

Another factor that might have an influence on the isolation rate of Campylobacter spp. is the age of the examined chickens (Newell et al., 2011). The contamination of broiler flocks by campylobacters generally occurrs late (after 15-20 days of rearing) due to ability of the gut flora of the young birds to provide good protection against campylobacter colonization (Laisney et al., 2004). The prevalence of Campylobacter spp. in chicken is expected to be high in broilers slaughtered at 5-6 weeks (Bouwknegt et al., 2004), while in older chickens, the prevalence decreases reflecting acquired immunity (Kalupahana et al., 2013). During the current study, the examined samples were collected from chickens at 6 weeks old explaining the relatively high isolation rate of campylobacters.

Moreover, the methodology; isolation and identification techniques, has an impact factor which affected the analytical results (Mead et al., 2010). For example, Salvat et al. (2017) noticed highly significant decrease of heavily campylobacter contaminated carcasses when sampling method changed (from neck to leg skin) in a traditional free range broiler production along 23 year survey program. The isolation methodologies are laborious, and there are many broths and agars available. Some studies have evaluated the effectiveness of different broths and agar plates for their ability to isolate campylobacter from several 
matrices to develop more efficient and lower cost methods (Gonsalves et al., 2016). Seliwiorstow et al. (2016) demonstrated the impact of culture medium on the recovery of campylobacters from fresh and frozen naturally contaminated poultry meat samples with a great effect on the detection of campylobacters. Also, Oyarzabal et al. (2005) concluded that certain agars and broths are better than others for the isolation of campylobacter form certain samples with regards to time, preparation, performance and cost.

Although all that mentioned possible reasons, there is need for further research to explain the possible reasons on Campylobacter spp. distribution differences among studied company farms (Huang et al., 2016).

The results obtained from both disc diffusion and broth microdilution testing methods in the current study showed that all $C$. jejuni and $C$. coli isolates (no=42) were $100 \%$ resistant to all examined macrolide agents. In accordance, the same findings were reported in Egypt (Hefny, 2014; Saad, 2014).

The uncontrolled and misuse of tylosin and erythromycin in poultry production in Egypt could be the reason for the high level of macrolides resistance in the current study. Ladely et al. (2007) and Lin et al. (2007) reported significantly increased frequencies of macrolides resistance when tylosin was administered at sub-therapeutic levels in Campylobacter species. Also, erythromycin resistance rate among $C$. jejuni and $C$. coli isolates increased after tylosin administration (Ladely et al., 2007). This conclusion was supported by Bester and Essack (2012) in South Africa, who reported that $88 \%$ of campylobacter isolates from poultry raised commercially; using macrolides agents, were macrolides resistant versus $0 \%$ for those isolates from small-scale family farms where no macrolide agents were used.

Unfortunately, resistance rates are much higher in parts of Asia and Africa; for example, in Nigeria, nearly $80 \%$ of strains are macrolides-resistant (Smith et al., 1999). In the contrary, $100 \%$ sensitivity of $C$. jejuni isolates was reported in South Korea (Oh et al., 2017) and Spain (Pérez-Boto et al., 2015), where the use of macrolides was restricted.

In conclusion, the relatively high isolation rate of campylobacters from different parts of chicken carcasses during the current study could be attributed to lack of hygienic measures in pluck-shop markets. Thus, the control of campylobacter incidence in poultry is a major public health strategy for prevention of human campylobacteriosis. Also, the high levels of macrolide resistance in $C$. jejuni and C. coli isolates were reported which could be attributed to the widespread use of macrolides in chicken production. The current study recommends further studies on the mechanisms macrolides resistance in campylobacters.

\section{REFERENCES}

Abd El-Tawab, A.A., Ammar, A.M., Ahmed, H.A., El Hofy, F.I., Hefny, A.A., 2015. Bacteriological and Molecular Identification of Campylobacter spp. in Chickens and Humans, at Zagazig City, Egypt. 
Benha veterinary medical journal 28 , 17-26.

Anderson, J., Horn, B.J., Gilpin, B.J., 2012. The prevalence and genetic diversity of Campylobacter spp. in domestic 'backyard' poultry in Canterbury, New Zealand. Zoonoses and public health 59, 52-60.

Awadallah, M., Ahmed, H., El-Gedawy, A., Saad, A., 2014. Molecular identification of $C$. jejuni and C. coli in chicken and humans, at Zagazig, Egypt, with reference to the survival of $C$. jejuni in chicken meat at refrigeration and freezing temperatures. International Food Research Journal 21.

Belanger, A.E., Shryock, T.R., 2007. Macrolide-resistant campylobacter: the meat of the matter. Journal of Antimicrobial Chemotherapy 60, 715-723.

Bester, L.A., Essack, S.Y., 2012. Observational study of the prevalence and antibiotic resistance of Campylobacter spp. from different poultry production systems in KwaZulu-Natal, South Africa. Journal of food protection $75,154-$ 159.

Bouwknegt, M., Van De Giessen, A., DamDeisz, W., Havelaar, A., Nagelkerke, N., Henken, A., 2004. Risk factors for the presence of Campylobacter spp. in Dutch broiler flocks. Preventive veterinary medicine 62, 35-49.
Bronnec, V., Turoňová, H., Bouju, A., Cruveiller, S., Rodrigues, R., Demnerova, K., Tresse, O., Haddad, N., Zagorec, M., 2016. Adhesion, biofilm formation, and genomic features of $C$. jejuni $\mathrm{Bf}$, an atypical strain able to grow under aerobic conditions. Frontiers in microbiology 7.

Ca-SFM, 2013. Comite' de l'Antibiogramme de la Socie'te' Franc, aise de Microbiologie; proposer les recommandations 2013.

Carrique-Mas, J.J., Bryant, J., Cuong, N., Hoang, N ،.Campbell, J., Hoang, N., Dung, T., Duy, D., Hoa, N., Thompson, C., 2014. An epidemiological investigation of campylobacter in pig and poultry farms in the Mekong delta of Vietnam. Epidemiology and infection 142, 1425.

Chang, Q., Wang, W., Regev-Yochay 'G., Lipsitch, M., Hanage, W.P., 2015. Antibiotics in agriculture and the risk to human health: how worried should we be? Evolutionary applications 8 , 240-247.

Chatur, Y.A., Brahmbhatt, M.N., Modi, S., Nayak, J.B., 2014. Fluoroquinolone resistance and detection of topoisomerase gene mutation in $C$. jejuni isolated from animal and human sources. International Journal of Current Microbiology and Applied Sciences (IJCMAS) 3, 773-783.

CLSI, 2012. Performance Standards for Antimicrobial Disk Susceptibility 
Tests; Approved Standard-Eleventh Edition, CLSI document M02-A11. Wayne, PA. Clinical and Laboratory Standards Institute 2012.

Da Silva, D.T., Tejada, T.S., Blum-Menezes, D., Dias, P.A., Timm, C.D., 2016. Campylobacter spp. isolated from poultry and humans, and their analysis using PFGE in southern Brazil. International journal of food microbiology 217, 189-194.

Dadi, L., Asrat, D., 2016. Prevalence and antimicrobial susceptibility profiles of thermotolerant campylobacter strains in retail raw meat products in Ethiopia. The Ethiopian Journal of Health Development (EJHD) 22.

Economou, V., Zisides, N., Gousia, P., Petsios, S., Sakkas, H., Soultos, N., Papadopoulou, C., 2015. Prevalence and antimicrobial profile of campylobacter isolates from freerange and conventional farming chicken meat during a 6-year survey. Food Control 56, 161-168.

EFSA, 2008. The community summary report on trends and sources of zoonoses, zoonotic agents and foodborne outbreaks in the European Union in 2008. EFSA Journal 8, 1496.

EFSA ‘ECDC, 2015. European food safety authority and the european centre for disease prevention and control; EU summary report on antimicrobial resistance in zoonotic and indicator bacteria from humans, animals and food in 2013. EFSA Journal 13, 4036.
Ellerbroek, L., Lienau, J.A., Klein, G., 2010. Campylobacter spp. in Broiler Flocks at Farm Level and the Potential for Cross-Contamination During Slaughter. Zoonoses and public health 57, e81-e88.

EUCAST, 2017. The European Committee on Antimicrobial Susceptibility Testing. Breakpoint tables for interpretation of MICs and zone diameters. Version 7.1, 2017. http://www.eucast.org.

Gblossi Bernadette, G., Eric Essoh, A., Solange, E., Natalie, G., Souleymane, B., Lamine Sébastien, N., Mireille, D., 2012. Prevalence and antimicrobial resistance of thermophilic campylobacter isolated from chicken in Côte d'Ivoire. International journal of microbiology 2012.

Gonsalves, C.C., Borsoi, A., Perdoncini, G., Rodrigues, L.B., do Nascimento, V.P., 2016. Campylobacter in broiler slaughter samples assessed by direct count on mCCDA and Campy-Cefex agar. brazilian journal of microbiology 47, 764-769.

Griggs, D.J., Johnson, M.M., Frost, J.A., Humphrey, T., Jørgensen, F., Piddock, L.J., 2005. Incidence and mechanism of ciprofloxacin resistance in Campylobacter spp. isolated from commercial poultry flocks in the United Kingdom before, during, and after fluoroquinolone treatment. Antimicrobial agents and chemotherapy 49, 699-707. 
Han, X., Zhu, D., Lai, H., Zeng, H., Zhou, K., Zou, L ‘.Wu, C., Han, G., Liu, S., 2016. Prevalence, antimicrobial resistance profiling and genetic diversity of $C$. jejuni and $C$. coli isolated from broilers at slaughter in China. Food Control 69, 160-170.

Hansson, I., Nyman, A., Lahti, E., Gustafsson, P., Engvall, E.O., 2015. Associations between campylobacter levels on chicken skin, underlying muscle, caecum and packaged fillets. Food microbiology 48, 178-181.

Hefny, A., 2014. Occurrence, antibiotic resistance and genotyping of $C$. jejuni strains isolated from chickens, their meat and humans Master thesis Bacteriology Department, Faculty of veterinary medicine Benha University, Egypt.

Henry, I., Reichardt, J., Denis, M., Cardinale, E., 2011. Prevalence and risk factors for Campylobacter spp. in chicken broiler flocks in Reunion Island (Indian Ocean). Preventive veterinary medicine 100, 64-70.

Huang, J., Zong, Q., Zhao, F., Zhu, J., Jiao, X.-a., 2016. Quantitative surveys of salmonella and campylobacter on retail raw chicken in Yangzhou, China. Food Control 59 ،73-86.

Iovine, N.M., Pursnani, S., Voldman, A., Wasserman, G., Blaser, M.J., Weinrauch, Y., 2008. Reactive nitrogen species contribute to innate host defense against C.jejuni. Infection and immunity 76, 986-993.
ISO, 2006. Microbiology of Food and Animal Feeding Stuffs - Horizontal Method for Detection and Enumeration of Campylobacter spp. Part 1: Detection Method. Geneva: International Organization for Standardization. [ISO 102721:2006. [

Jorgensen, F., Ellis-Iversen, J., Rushton, S., Bull, S., Harris, S ‘.Bryan, S., Gonzalez, A., Humphrey, T., 2011. Influence of season and geography on $C$. jejuni and $C$. coli subtypes in housed broiler flocks reared in Great Britain. Applied and environmental microbiology 77, 3741-3748.

Kalupahana, R., Kottawatta, K., Kanankege, K., van Bergen, M., Abeynayake, P., Wagenaar, J., 2013. Colonization of Campylobacter spp. in broiler chickens and laying hens reared in tropical climates with lowbiosecurity housing. Applied and environmental microbiology 79, 393395.

Ladely, S.R., Harrison, M.A., Fedorka-Cray, P.J., Berrang, M.E., Englen, M.D., Meinersmann, R.J., 2007. Development of macrolide-resistant campylobacter in broilers administered subtherapeutic or therapeutic concentrations of tylosin. Journal of food protection 70 ،19451951.

LaGier, M.J., Joseph, L.A., Passaretti, T.V., Musser, K.A., Cirino, N.M., 2004. A real-time multiplexed PCR assay for rapid detection and differentiation of 
C. jejuni and C. coli. Molecular and cellular probes 18, 275-282.

Laisney, M.-J., Gillard, M.-O., Salvat, G., 2004. Influence of bird strain on competitive exclusion of $C$. jejuni in young chicks. British poultry science 45, 49-54.

Lin, J., Yan, M., Sahin, O., Pereira, S., Chang, Y.-J., Zhang, Q., 2007. Effect of macrolide usage on emergence of erythromycin-resistant campylobacter isolates in chickens. Antimicrobial agents and chemotherapy 51, 1678-1686.

Mäesaar, M., Kramarenko, T., Meremäe, K., Sõgel, J., Lillenberg, M., Häkkinen, L., Ivanova, M., Kovalenko, K., Hörman, A., Hänninen, M.L., 2015. Antimicrobial resistance profiles of Campylobacter spp. isolated from broiler chicken meat of Estonian, Latvian and Lithuanian Origin at Estonian retail level and from patients with severe enteric infections in Estonia. Zoonoses and public health, 63, 89-96.

Mäesaar, M., Praakle, K., Meremäe, K., Kramarenko, T., Sõgel, J., Viltrop, A., Muutra, K., Kovalenko, K., Matt, D., Hörman, A., 2014. Prevalence and counts of Campylobacter spp. in poultry meat at retail level in Estonia. Food control 44, 72-77.

Marinou, I., Bersimis, S., Ioannidis, A., Nicolaou, C., Mitroussia-Ziouva, A., Legakis, N.J., Chatzipanagiotou, S., 2012. Identification and antimicrobial resistance of Campylobacter spp. isolated from animal sources. Frontiers in microbiology 3,58 .

Mdegela, R.H., Nonga, H.E., Ngowi, H.A., Kazwala, R.R., 2006. Prevalence of thermophilic campylobacter infections in humans, chickens and crows in Morogoro, Tanzania. Journal of veterinary medicine. B, Infectious diseases and veterinary public health 53, 116-121.

Mead, G., Lammerding, A.M., Cox, N., Doyle, M.P., Humbert, F., Kulikovskiy, A., Panin, A., Nascimento, V.P.D., Wierup, M., 2010. Scientific and technical factors affecting the setting of salmonella criteria for raw poultry: a global perspective. Journal of food protection 73, 1566-1590.

Megraud, F., $1987 . \quad$ Diagnostic bacteriologique des infections à campylobacter. Revue Française des Laboratoires 156, 2-16.

Menna, L.F., Matteoli, G., Fontanella, M., Cuomo, A., De Paola, A., Pepe, T., Di Marco, I., Dipineto, L., 2005. Prevalence of $C$. jejuni in poultry breeder flocks. Italian Journal of Animal Science 4, 269-271.

Meremäe, K., Elias, P., Tamme, T., Kramarenko, T., Lillenberg, M., Karus, A., Hänninen, M.-L., Roasto, M., 2010. The occurrence of Campylobacter spp. in Estonian broiler chicken production in 2002 2007. Food Control 21, 272-275.

Messad, S., Hamdi, T.-M., Bouhamed, R., Ramdani-Bouguessa, N., Tazir, M., 
Bacteriological and Molecular Identification of some Campylobacter Species in Broilers and their Macrolide Resistance Profile

2014. Frequency of contamination and antimicrobial resistance of thermotolerant campylobacter isolated from some broiler farms and slaughterhouses in the region of Algiers. Food control 40, 324-328.

Miwa, N., Takegahara, Y., Terai, K., Kato, H., Takeuchi, T., 2003. Campylobacter jejuni contamination on broiler carcasses of $C$. jejuninegative flocks during processing in a Japanese slaughterhouse. International journal of food microbiology 84, 105-109.

Moore, J.E., Corcoran, D., Dooley, J.S., Fanning, S., Lucey, B., Matsuda, M., McDowell, D.A., Megraud, F., Millar, B.C., O'Mahony, R., O'Riordan, L ‘.O'Rourke, M., Rao, J.R., Rooney, P.J., Sails, A., Whyte, P., 2005. Campylobacter. Veterinary research 36, 351-382.

Neimann, J., Engberg, J., Mølbak, K., Wegener, H.C., 2003. A case--control study of risk factors for sporadic campylobacter infections in Denmark. Epidemiology \& Infection 130, 353-366.

Newell, D., Elvers, K., Dopfer, D., Hansson, I., Jones, P., James, S., Gittins, J., Stern, N., Davies, R., Connerton, I., 2011. Biosecurity-based interventions and strategies to reduce Campylobacter spp. on poultry farms. Applied and environmental microbiology 77, 8605-8614.

Oh, J.-Y., Kwon, Y.-K., Wei, B., Jang, H.K., Lim, S.-K., Kim, C.-H., Jung, S.-
C., Kang, M.S., 2017. Epidemiological relationships of $C$. jejuni strains isolated from humans and chickens in South Korea. Journal of Microbiology 55, 13-20.

Oxoid, 2006. Oxoid Manual 9th Edition 2006.

Oyarzabal, O.A., Macklin, K.S., Barbaree, J.M., Miller, R.S., 2005. Evaluation of agar plates for direct enumeration of Campylobacter spp. from poultry carcass rinses. Applied and environmental microbiology 71, 3351-3354.

Parkar, S.F., Sachdev, D., Kamble, A., Suresh, G., Munot, H., Hanagal, D., Shouche, Y., Kapadnis, B., 2013. Prevalence, seasonality and antibiotic susceptibility of thermophilic campylobacters in ceca and carcasses of poultry birds in the live-bird market. African Journal of Microbiology Research 7, 24422453.

Pedonese, F., Nuvoloni, R., Turchi, B., Torracca, B., Di Giannatale, E., Marotta, F., Cerri, D., 2017. Prevalence, phenotypic and genetic diversity of campylobacter in poultry fresh meat and poultry products on retail sale in Tuscany (Italy). Veterinaria italiana 53, 29.

Pérez-Boto, D., Acebo, P., García-Peña, F.J., Abad, J.C., Echeita, M.A., Amblar, M., 2015. Isolation of a point mutation associated with altered expression of the cmeABC efflux pump in a multidrug-resistant $C$. 
jejuni population of poultry origin. Journal of Global Antimicrobial Resistance 3, 115-122.

Pezzotti, G., Serafin, A., Luzzi, I., Mioni, R., Milan, M., Perin, R .r.r. Occurrence and resistance to antibiotics of $C$. jejuni and $C$. coli in animals and meat in northeastern Italy. International journal of food microbiology 82, 281-287.

Saad, A.E.M., 2014. Zoonotic Importance of campylobacteriosis at Sharkia Province. Master thesis Zoonoses Department, Faculty of veterinary medicine Zagazig University, Egypt.

Sabike, I.I., Uemura, R., Kirino, Y., Mekata, H., Sekiguchi, S., Farid, A.S., Goto, Y., Horii, Y., Yamazaki, W., 2017. Assessment of the $C$. jejuni and $C$. coli in broiler chicken ceca by conventional culture and loopmediated isothermal amplification method. Food Control 74, 107-111.

Salihu, M., Junaidu, A., Magaji, A., Yakubu, Y., 2012. Prevalence and antimicrobial resistance of thermophilic campylobacter isolates from commercial broiler flocks in Sokoto, Nigeria. Research Journal of Veterinary Sciences 5, 51-58.

Sallam, K.I., 2001. Campylobacter contamination in retailed chicken carcasses from Mansoura, Egypt, and its relation to public health. Alexandria Journal of Veterinary Sciences 17.

Sallam, K.I., 2007. Prevalence of campylobacter in chicken and chicken by-products retailed in Sapporo area, Hokkaido, Japan. Food Control 18, 1113-1120.

Salvat, G., Guyot, M., Protino, J., 2017. Monitoring salmonella, campylobacter, E. coli and Staphylococcus aureus in traditional free-range 'Label Rouge'broiler production: a 23-year survey programme. Journal of applied microbiology 122, 248-256.

Seliwiorstow, T., De Zutter, L., Houf, K., Botteldoorn, N., Baré, J., Van Damme, I., 2016. Comparative performance of isolation methods using Preston broth, Bolton broth and their modifications for the detection of Campylobacter spp. from naturally contaminated fresh and frozen raw poultry meat. International journal of food microbiology 234, 60-64.

Shih, D.Y.-C., 2000. Isolation and identification of enteropathogenic Campylobacter spp. from chicken samples in Taipei. Journal of food protection 63, 304-308.

Silva, J., Leite, D., Fernandes, M., Mena, C., Gibbs, P.A., Teixeira, P., 2011 . Campylobacter spp. as a foodborne pathogen: a review. Frontiers in microbiology 2, 200.

Smith, S., Sansa, T., Coker, A., 1999. Antibiotic susceptibility patterns and beta-lactamase production of animal and human isolates of campylobacter in Lagos, Nigeria. Zeitschrift für Naturforschung C 54, 583-586. 
Stella, S., Soncini, G., Ziino, G., Panebianco, A., Pedonese, F., Nuvoloni, R., Di Giannatale, E., Colavita, G., Alberghini, L., Giaccone, V., 2017. Prevalence and quantification of thermophilic Campylobacter spp. in Italian retail poultry meat: Analysis of influencing factors. Food microbiology 62, 232-238.

Studer, E., Lüthy, J., Hübner, P., 1999. Study of the presence of $C$. jejuni and $C$. coli in sand samples from four Swiss chicken farms. Research in microbiology 150, 213-219.

Takkinen, J., Ammon, A., Robstad, O., Breuer, T., 2002. The Campylobacter Working Group. European Survey on campylobacter Surveillance and Diagnostics 2000, campylobacter Infections. . Report to the European Commission, DG SANCO 4 ،Berlin, 1-107.

Udayamputhoor, R.S., Hariharan, H., Van Lunen, T.A., Lewis, P.J., Heaney, S., Price, L., Woodward, D., 2003. Effects of diet formulations containing proteins from different sources on intestinal colonization by C. jejuni in broiler chickens . Canadian journal of veterinary research 67, 204-212.

Vandepitte, J., Verhaegen, J., 2003. Basic laboratory procedures in clinical bacteriology. 2nd edition. World Health Organization, Geneva, Switzerland, 2003, 42- 43.

Waino, M., Bang, D.D., Lund, M., Nordentoft, S., Andersen, J.S.,
Pedersen, K., Madsen, M., 2003. Identification of campylobacteria isolated from Danish broilers by phenotypic tests and species-specific PCR assays. Journal of applied microbiology 95, 649-655.

Wang, G., Clark, C.G., Taylor ‘T.M., Pucknell, C., Barton, C., Price, L., Woodward, D.L., Rodgers, F.G., 2002. Colony multiplex PCR assay for identification and differentiation of C. jejuni, C. coli, C. lari, $C$. upsaliensis, and C. fetus subsp. fetus. Journal of clinical microbiology,40, 4744-4747.

Wei, B., Cha, S.-Y., Yoon, R.-H., Kang, M., Roh, J.-H., Seo, H.-S., Lee, J.-A., Jang, H.-K., 2016. Prevalence and antimicrobial resistance of Campylobacter spp. isolated from retail chicken and duck meat in South Korea. Food Control 62, 63-68.

Zbrun, M., Olivero, C., Romero-Scharpen, A., Rossler, E., Soto, L., Astesana, D., Blajman, J., Berisvil, A., Signorini, M., Frizzo, L., 2015. Antimicrobial resistance in thermotolerant campylobacter isolated from different stages of the poultry meat supply chain in Argentina. Food Control 57, 136141.

Zhang, T., Luo, Q., Chen, Y., Li, T., Wen, G., Zhang, R., Luo, L., Lu, Q., Ai, D., Wang, H., 2016. Molecular epidemiology, virulence determinants and antimicrobial resistance of campylobacter 
spreading in retail chicken meat in Central China. Gut Pathog 8, 48.

Zhu, J., Yao, B., Song, X., Wang, Y., Cui, S., Xu, H., Yang, B., Huang, J., Liu, G., Yang, X., 2016. Prevalence and Quantification of campylobacter Contamination on Raw Chicken Carcasses for Retail Sale in China. Food Control.
Zilbauer, M., Dorrell, N., Wren, B.W., Bajaj-Elliott, $\quad$ M., 2008. Campylobacter jejuni-mediated disease pathogenesis: an update. Transactions of the Royal Society of Tropical Medicine and Hygiene 102, 123-129.

\section{التصنيف البكتريولوجي و الجزيئي لأنواع الكامبيلوباكتر في دجاج التسميين وتحديد مقاومته للماكروليد}

أشرف عواد عبد التواب'، أحمد محمد عمارّ، هبة أحمد عبد اللّّ ، فاطمة إبراهيم الحوفي'، أحمد حفني عبد الفتاح؛

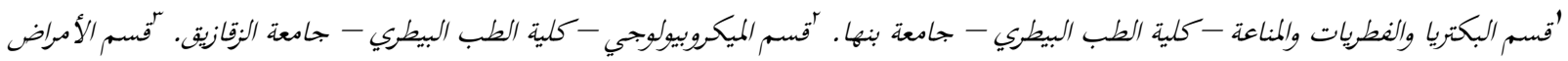
المشتركة- كلية الطب البيطري - جامعة الزقازيق. ثالمستشفي البيطري - كلية الطب البيطري - جامعة الزقازيق.

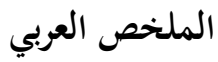

جنس الكامبيلوباكتر متضمنا أنواع عديدة ذو أهمية كبيرة و يعتبر من المسببات الكبري للإسهالات الحادة في الإنسان علي مستوي العالم. تم إجراء هذه الدراسة لتحديد مدي تواجد الكامبيلوبكتر الحرارية في دجاج التسمين و تحديد مدي مقاومتها للماكروليد خصوصا في كلا من الكامبيلوباكتر جوجيناي و الكامبيلوباكتر كولي و تم جمع ما بحموعه 140 عينة (ع بr مسحة من الجلد و 101 من كل من لحم الصدر و الفخذ وجلد الرقبة) من دجاج اللحم في سن الذبح من منافذ البيع مدينة المحلية في الزقازيق بمحافظة الشرقية

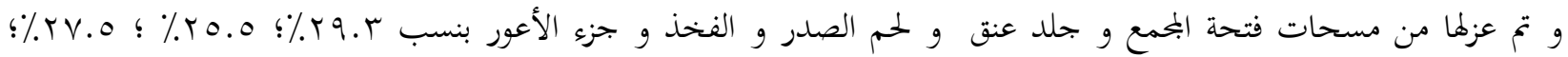

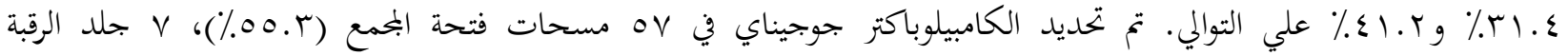

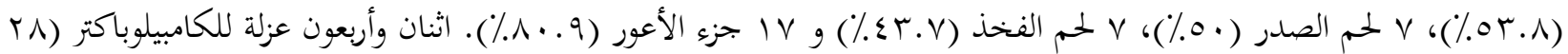
كامبيلوباكتر جوجيناي و \& ا الكامبيلوباكتر كولي الذي تم تصنيفهم بنائا عن الإختبارات الكيميائية) تم التأكد منها جينيا بالإعتماد علي جين بr اس الريبوسومي للحمض النووي الريبي و كذلك تم تأكيد عزلات الكامبيلوباكتر جوجيناي وباستخدام تفاعل البلمرة المتسلسل الوقتي الفعلي للهيبوريكاز جين وكذلك استخدم جين جلي أ لتميز الكامبيلوباكتر كولي (عدد= ع ا) وتم تقييم العزلات التي تم تأكيدها جينا لتحديد مقاومتها للماكروليد باستخدام نشر القرص وطرق اختبار التخفيف الجزئي للمرق و وجد اها كلها مقاومة للماكروليد لذا المزيد من الأبحاث ضرورية اتوضيح طريقة حدوث هذه المقاومة. 